UDC 612.1

https://doi.org/10.15407/ubj88.06.076

\title{
THE RELATIONSHIP BETWEEN SERUM FERRITIN LEVELS AND SERUM LIPIDS AND HDL FUNCTION WITH RESPECT TO AGE AND GENDER
}

\author{
HAMIT YASAR ELLIDAG ${ }^{1 *}$ ESIN EREN ${ }^{1}$, MEHMET AKDAG ${ }^{2}$, \\ OZLEM GIRAY ${ }^{1}$, KEMAL KIRAZ ${ }^{3}$, NECAT YILMAZ ${ }^{1}$ \\ ${ }^{1}$ Central Laboratories of Antalya Training and Research Hospital, University \\ of Medical Sciences, Ministry of Health, Antalya, Turkey; \\ ${ }^{2}$ ENT Clinic of Antalya Ataturk State Hospital, Ministry of Health, Antalya, Turkey; \\ ${ }^{3}$ Department of Pulmonology, Antalya Ataturk State Hospital, \\ Ministry of Health, Antalya, Turkey; \\ e-mail: hayael1980@hotmail.com
}

\begin{abstract}
Elevated serum ferritin (SFer) levels have been associated with chronic diseases such as coronary heart disease and diabetes mellitus type 2. The aim of this study was to examine the relationship between SFer levels and serum lipid parameters, and how this relation changes in terms of age and gender. Additionally, we investigated a possible relationship between SFer levels and high-density lipoprotein (HDL) function. SFer levels and lipid panel (total cholesterol (TC), triglyceride (TG), low-density lipoprotein-cholesterol (LDL-C) and HDL-C) of 4205 people (3139 women, 1066 men) were examined retrospectively. Study population was classified according to age and gender. Separately, 100 subjects (52 women, 48 men) were randomly recruited to investigate the relation between SFer levels, and HDL dependent paraoxonase-1 (PON1) and arylesterase (ARE) activities. In all age groups, women's SFer levels were found to be significantly lower and HDL-C levels significantly higher compared to men. In the 50-70 ages range, TC and LDL-C levels of women were found to be significantly higher than those of men $(P<0.01)$. SFer levels tended to increase with age in women. Correlation analyses revealed a negative correlation between levels of SFer and HDL-C, while positive correlations existed between levels of SFer, and TC, TG and LDL-C. There was no significant correlation between SFer levels and PON1 or ARE activities. The finding that increased SFer levels are accompanied by increased serum TC, TG and LDL-C levels may help us to explain the increased risk of metabolic disorders and cardiovascular disease in postmenopausal women.
\end{abstract}

Ke y words: ferritin, lipid metabolism, paraoxonase, arylesterase, HDL, LDL.

$\mathrm{F}$ ollowing the transition to aerobic respiration, transition metal elements, through evolutionary processes, have enabled delivery of oxygen to peripheral tissues of increasingly complex organisms. Since iron reacts with oxygen spontaneously (without energy consumption), as well as exchange electrons easily, it functions as an $\mathrm{O}_{2}$ carrier in many organisms and is essential for these, including humans [1, 2]. Additionally, iron is a part of the structures of many proteins, such as haemoglobin, myoglobin and cytochromes, and functions as a cofactor in various enzymes in numerous biochemical reactions [3]. Nonetheless, excessive accumulation of iron in the organism leads to cellular dysfunction and death due to formation of free radicals and lipid peroxidation [4]. Therefore iron metabolism re- quires strict control. There is no direct physiological mechanism in humans to excrete iron and its excess is stored in ferritin. Ferritin is an intracellular protein of $450 \mathrm{kDa}$ molecular weight, consisting of 24 subunits. Ferritin serves to store iron in a safe form [5].

There are many publications that have found that elevated serum ferritin (SFer) levels are linked with chronic diseases, such as coronary heart disease and diabetes mellitus [6-10]. Sullivan et al. have proposed for the first time that in postmenopausal women, increased body iron stores may lead to an increase in cardiovascular disease (CVD) incidence [11]. High SFer levels were shown to be associated with increased risk of myocardial infarction and coronary artery disease related mortality [12]. Fur- 
thermore, links have been found between elevated SFer levels and such disorders as insulin resistance, hypertension and type-2 diabetes mellitus [13, 14]. However, other studies have found no relationship between the level of SFer and risk of CVD [15-18].

High serum levels of total cholesterol (TC), triglyceride (TG) and low-density lipoprotein cholesterol (LDL-C), and low levels of high-density lipoprotein cholesterol (HDL-C) are among the major risk factors for CVD [19, 20]. There are animal and human studies indicating a link between iron and lipid metabolisms. For example, an iron-deficient diet in rats exerted broad influence on gene expression patterns of the lipid metabolism compared with a normal diet [21]. According to two studies that examined the relationship between lipid parameters and iron deficiency anemia in women, significant variations were observed in lipid parameters before administrating iron therapy, which were partly alleviated afterwards [22, 23].

Despite the cited research, the number of studies investigating the relation between the serum lipid panel and SFer levels in large sample sizes is limited. In particular, the categorical influence of age and gender on this association remains unknown. Furthermore, the relationship between serum lipid and SFer levels has been probed within certain populations, while variations in genetic makeup and dietary habits are known to affect the lipid panel and iron stores [24]. An analysis directly comparing the SFer and serum lipid levels in the Turkish population has not yet been performed. Therefore, in our study we aimed to investigate the relation between ferritin and lipid parameters, and whether and how this relation changes in terms of age and gender.

Another purpose of this research was to demonstrate a possible relationship between SFer levels and HDL dependent paraoxonase-1 (EC 3.1.8.1) (PON1) and arylesterase (EC 3.1.1.2) (ARE) activities.

\section{Materials and Methods}

Study design. A total of 4205 subjects (3139 women, 1066 men, mean age: 43), who had visited various clinics of Antalya Training and Research Hospital between January 2013 and January 2015 were included in this study. The study group was selected by examining the patient data registered in the laboratory information system (LIS) of the hospital. Accordingly, all inpatients (from the departments of cardiology, cardiovascular surgery, general surgery, neonatology, paediatrics, oncology, etc. and from the cardiac intensive care and intensive care units) were excluded from the study. Furthermore, children under 20 and people over 70 years of age, pregnant women, oncology patients, thalassemia patients, and patients with chronic liver disease or chronic kidney disease were excluded from the patients involved in the study. The lipid panel (TC, TG, LDL-C and HDL-C levels) and SFer levels of the study group had been determined, which was analyzed retrospectively. Throughout the said interval, the laboratory equipment and methods of measurement have remained unchanged.

An additional 100 subjects (52 women, 48 men, mean age: 46), whose SFer and HDL-C parameters had been measured in our laboratory, were randomly selected for PON1 and ARE activity analysis.

The study was performed in accordance with ethical standards established by the Declaration of Helsinki and approved by the local ethics committee.

Lipid panel (TC, TG, LDL-C, and HDL-C) analysis. Levels of TC and TG were measured with Beckmann Coulter commercial reagents using an AU5800 AU analyzer (Beckman Coulter, Inc., CA, USA). Triglycerides are hydrolyzed by lipases into glycerol and fatty acids. Glycerol is phosphorylated by glycerol kinase (EC 2.7.1.30) to produce glycerol-3-phosphate. Glycerol-3-phosphate is then oxidized by glycerol-3-phosphate oxidase (EC 1.1.3.21), creating hydrogen peroxide $\left(\mathrm{H}_{2} \mathrm{O}_{2}\right)$. The resulting $\mathrm{H}_{2} \mathrm{O}_{2}$ is then turned into a chromophore by peroxidase, which is read at $660 / 800 \mathrm{~nm}$. The increase in absorbance is thus proportional to the triglyceride content in the sample. In cholesterol analysis, free cholesterol is formed from cholesterol esters by cholesterol esterase (EC 3.1.1.13) reaction. In the presence of both cholesterol oxidase (EC 1.1.3.6) and peroxidase, the resulting free cholesterol leads to a spectrophotometric absorbance change that is used for determining the cholesterol concentration in the sample.

HDL-C was analyzed with Beckmann Coulter commercial reagents using an AU5800 AU Analyzer (Beckman Coulter, Inc., CA, USA). Test principle is essentially based on immunoinhibition and enzymatic colour reaction. The anti-betalipoprotein antibody binds to lipoproteins other than HDL (LDL, VLDL and chylomicrons). The enzyme activities of these antigen-antibody complexes are inhibited by the addition of another reagent. HDL-C concentration is determined with an enzyme chromogen system. Intra-day and inter-day coefficients of variation of 
TC, TG and HDL-C were found to be less than $4 \%$. LDL-C concentration was calculated by the Friedewald formula [LDL-C = TC - HDL-C - (TG/5)] [25].

Measurement of SFer levels. SFer levels were measured with the chemiluminescence method using a UniCel ${ }^{\circledR}$ DxI800 Analyzer (Beckman Coulter, Inc., CA, USA). The ferritin assay is a two-site immunoenzymatic ("sandwich") assay. A sample is added to a reaction vessel with goat anti-ferritinalkaline phosphatase conjugate, and paramagnetic particles coated with goat anti-mouse: mouse antiferritin complexes. Serum or plasma ferritin binds to the immobilized monoclonal anti-ferritin in the solid phase, while the goat anti-ferritin enzyme conjugate reacts with different antigenic sites on the ferritin molecules. This "sandwich" conformation serves to maximise specificity. Separation in a magnetic field and washing removes materials not bound to the solid phase. This washing step eliminates any potential cross-reactants in the sample, as well as the excess anti-ferritin-enzyme conjugate, which could otherwise increase the background signal and reduce sensitivity. A chemiluminescent substrate, Lumi-Phos ${ }^{\circledR} 530$, is added to the reaction vessel and light generated by the reaction is measured with a luminometer. The photon production is proportional to the amount of ferritin in the sample. Intra-day and inter-day coefficients of variation of ferritin were found to be less than $6 \%$.

Measurement of PON1 and ARE enzyme activities in serum. PON1 and ARE enzyme activities were measured using commercially available kits (Rel Assay Diagnostics ${ }^{\circledR}$, Gaziantep, Turkey). PON1 activity measurement method is fully automated and involves an appropriate Tris buffer containing calcium ions, which is a cofactor of the PON1 enzyme. A linear increase in the absorbance of p-nitrophenol, produced from paraoxon, is followed in a kinetic measurement mode. The non-enzymatic hydrolysis of paraoxon is subtracted from the total rate of hydrolysis. The molar absorptivity of p-nitrophenol is $18.290 \mathrm{M}^{-1} \cdot \mathrm{cm}^{-1}$ and one unit of paraoxonase activity is equal to $1 \mathrm{~mol}$ of paraoxon hydrolyzed per liter per minute at $37^{\circ} \mathrm{C}$ [26]. Phenylacetate was used as a substrate to measure ARE activity. PON1, present in the sample, hydrolyses phenylacetate to its products, phenol and acetic acid. The phenol produced is colorimetrically measured via oxidative coupling with 4-aminoantipyrine and potassium ferricyanide. Non-enzymatic hydrolysis of phenyl acetate is then subtracted from the total rate of hydrolysis.
The molar absorptivity of the coloured complex is $4,000 \mathrm{M}^{-1} \cdot \mathrm{cm}^{-1}$ and one unit of arylesterase activity is equal to $1 \mathrm{mmol}$ of phenylacetate hydrolyzed per litre per minute at $37^{\circ} \mathrm{C}$ [27].

Statistical analysis. SPSS (version 11.0 for Windows $\left.{ }^{\circledR}\right)$ statistical software was used for the evaluation of the data. The distribution of the collected data was examined by Kolmogorov-Smirnov test. Comparison of data showing non-normal distribution was performed via Mann-Whitney U test. Spearman correlation test was used for the correlation analysis. $P<0.05$ was considered as statistically significant.

\section{Results and Discussion}

According to the demographic data, the average age was 43.34 and women accounted for $70 \%$ of the study group (Table 1, A). Once the study group was categorized by gender, the women were found to be younger. There was no significant difference between men and women in terms of TC and LDL-C; however TG levels were significantly higher in men. As expected, compared to men, SFer levels were significantly lower and HDL-C concentrations were significantly higher in women (Table $1, B$ ).

The subjects in the study population were divided into "decade subgroups" between 20 and 70 (20-29, 30-39, etc.), and lipid panel and SFer levels of these subgroups were analyzed for each gender. In all decade subgroups women's SFer levels were significantly lower than men's (Table 2). In the 20-29 age subgroup, women's HDL-C concentrations were significantly higher and TG levels were significantly lower than men's. Women in the 30-39 age subgroup had lower TC, TG and LDL-C levels, and higher HDL-C concentrations compared to men. In the 4049 age subgroup, women had higher HDL-C and lower TG levels compared to men. In women older than 50 years old, TC, LDL-C and HDL-C levels were higher compared to men (Table 2).

The correlation analysis between SFer levels and lipid parameters in the study group has revealed positive correlations between SFer and TC, TG and LDL-C levels, and a negative correlation between SFer and HDL-C. Once women and men were separately evaluated, women had positive correlations between SFer and TC, TG and LDL-C levels, and a negative correlation between SFer and HDL-C. In men, there was a negative correlation between SFer and HDL-C levels, and a positive correlation between SFer and TG (Table 3). 
Table 1. A-Demographic and serum parameters of the study population

\begin{tabular}{|l|c|}
\hline Age, mean \pm SD & $43.34 \pm 13.50$ \\
\hline Women, $n(\%)$ & $3139(69.9 \%)$ \\
\hline Men, $n(\%)$ & $1566(30.1 \%)$ \\
\hline SFer, mean \pm SD, ng/ml & $54.8 \pm 163.3$ \\
\hline TC, mean \pm SD, mg/dl & $194.9 \pm 47.2$ \\
\hline TG, mean \pm SD, mg/dl & $134.1 \pm 95.2$ \\
\hline LDL-C, mean \pm SD, mg/dl & $119.3 \pm 39.4$ \\
\hline HDL-C, mean \pm SD, mg/dl & $50.3 \pm 14.4$ \\
\hline
\end{tabular}

Table 1. B-Distribution of parameters between genders

\begin{tabular}{|l|c|c|c|}
\hline \multicolumn{1}{|c|}{ Parameters } & $\begin{array}{c}\text { Women } \\
(n=353)\end{array}$ & $\begin{array}{c}\text { Men } \\
(n=1066)\end{array}$ & $P$ \\
\hline Age & $39(39-40)$ & $50(49-51)$ & $<0.01^{*}$ \\
\hline $\begin{array}{l}\text { SFer, median } \\
\text { (95\% CI), ng/ml }\end{array}$ & $\begin{array}{c}18 \\
(17-19)\end{array}$ & $\begin{array}{c}57 \\
(53-62)\end{array}$ & $<0.01^{*}$ \\
\hline $\begin{array}{l}\text { TC, median } \\
\text { (95\% CI), mg/dl }\end{array}$ & $\begin{array}{c}191 \\
(189-193)\end{array}$ & $\begin{array}{c}191 \\
(187-194)\end{array}$ & 0.07 \\
\hline $\begin{array}{l}\text { TG, median } \\
\text { (95\% CI), mg/dl }\end{array}$ & $\begin{array}{c}104 \\
(101-106)\end{array}$ & $\begin{array}{c}132 \\
(126-136)\end{array}$ & $<0.01^{*}$ \\
\hline $\begin{array}{l}\text { LDL-C, } \\
\text { median(95\% }\end{array}$ & $\begin{array}{c}115 \\
\text { CI), mg/dl }\end{array}$ & $\begin{array}{c}116 \\
(114-117)\end{array}$ & 0.86 \\
\hline $\begin{array}{l}\text { HDL-C, median } \\
\text { (95\% CI), mg/dl }\end{array}$ & $\begin{array}{c}51 \\
(51-52)\end{array}$ & $\begin{array}{c}42 \\
(41-43)\end{array}$ & $<0.01^{*}$ \\
\hline
\end{tabular}

SFer, serum ferritin; TC, total cholesterol; TG, total triglyceride; LDL-C, low-density lipoprotein-cholesterol; HDL-C, high-density lipoprotein-cholesterol; SD, standard deviation; CI, confidence interval. Reference ranges: SFer for female 10-300, for male 15-350; $\mathrm{TC}<200$; TG $<150$; LDL-C $<100$; HDL-C for female $>50$, for male $>40$. $*$ Statistically significant difference $(P<0.05)$

We divided the study group according to cut-off levels for the dyslipidemia classification recommended by the National Cholesterol Education Program and the Adult Treatment Panel III [28]. Accordingly, subjects with high TC, TG and LDL-C levels had higher SFer levels than those with normal lipid parameters. Conversely, both women and men with low HDL-C levels had higher SFer levels (Table 4).

Being an important indicator of HDL function, PON1 and ARE enzyme activities and their relation with SFer levels were also assessed in our study. For this purpose, we applied PON1 and ARE analyses to 100 randomly selected subjects' sera that already had SFer and HDL-C tests in our laboratory. Interestingly, despite there was a negative correlation between SFer and HDL-C levels $(r=-0.446$, $P<0.01$ ) in these patients, in agreement with the correlation in the main study group, there was no correlation between SFer and PON1 or ARE activity levels. Likewise, there was no statistically significant relationship between the gender of these subjects and PON1 or ARE activities (Table 5).

The results of our study in which we investigated the relation between ferritin and lipid levels can be summarized as follows:

I. In all age groups, SFer was significantly lower in women compared to men (Table 1).

II. In all age groups, despite the variation in other lipid parameters, HDL-C levels were significantly higher in women than those in men (Table 1).

III. In women older than 50, TC and LDL-C levels were significantly higher compared to men (Table 2).

IV. When correlation analyses between SFer and lipid parameters in the study group were performed, we found a strong correlation between SFer and HDL-C levels $(r=-0.247, P<0.01)$. When the study group was divided by gender, this correlation was stronger in men (Table 3).

V. Recommended lipid parameters [28] were associated with lower SFer levels (Table 4).

VI. No correlation was detected between SFer levels and PON1 or ARE activities, which are important indicators of HDL function.

The first observation that showed an association between serum ferritin levels and CVD is a largescale study (1931 Finnish men) conducted in 1992 [12]. Salonen et al. have found that the risk of acute myocardial infarction was 2.2 times higher in men whose SFer levels were higher than $200 \mathrm{ng} / \mathrm{ml}$. In the same study, high SFer levels were accompanied by high LDL-C levels. A subsequent study conducted in Finland has confirmed these findings [29]. In another study involving 11,471 women, postmenopausal women with higher SFer levels were associated with increased risk of ischemic stroke [30]. Wolff et al. have found increased SFer levels were linked to carotid artery atherosclerosis in both men and women [31]. Similarly, in a study population of 12,033 young Korean men, Sung et al. have suggested that there was an independent association between SFer levels and coronary artery calcium content, and also that 
Ta ble 2. The distribution of the lipid panel and SFer levels with respect to age and gender

\begin{tabular}{|c|c|c|c|}
\hline \multicolumn{4}{|c|}{ 20-29 age } \\
\hline Parameters & Women $(n=659)$ & Men $(n=125)$ & $P$ \\
\hline SFer, median (95\% CI), ng/ml & $14(13-15)$ & $53(46-66)$ & $<0.01^{*}$ \\
\hline TC, median (95\% CI), mg/dl & $166(163-170)$ & $159(150-166)$ & 0.07 \\
\hline TG, median (95\% CI), mg/dl & $80(78-84)$ & $101(86-114)$ & $<0.01^{*}$ \\
\hline LDL-C, median (95\% CI), mg/dl & 95 (94-98) & $95(88-101)$ & 0.87 \\
\hline HDL-C, median (95\% CI), mg/dl & $51(50-52)$ & $41(39-44)$ & $<0.01^{*}$ \\
\hline \multicolumn{4}{|c|}{ 30-39 age } \\
\hline Parameters & Women $(n=935)$ & Men $(n=173)$ & $P$ \\
\hline SFer, median (95\% CI), ng/ml & $12(11-14)$ & $62(56-76)$ & $<0.01^{*}$ \\
\hline TC, median (95\% CI), mg/dl & $184(181-187)$ & 193 (184-199) & $0.02 *$ \\
\hline TG, median (95\% CI), mg/dl & $92(87-97)$ & $126(114-143)$ & $<0.01^{*}$ \\
\hline LDL-C, median (95\% CI), mg/dl & $109(107-112)$ & $120(113-127)$ & $<0.01^{*}$ \\
\hline HDL-C, median (95\% CI), mg/dl & $52(51-54)$ & $41(40-42)$ & $<0.01^{*}$ \\
\hline \multicolumn{4}{|c|}{ 40-49 age } \\
\hline Parameters & Women $(n=587)$ & $\operatorname{Men}(n=226)$ & $P$ \\
\hline SFer, median (95\% CI), ng/ml & $16(14-17)$ & $71(60-80)$ & $<0.01^{*}$ \\
\hline TC, median (95\% CI), mg/dl & $201(198-206)$ & $198(191-206)$ & 0.68 \\
\hline TG, median (95\% CI), mg/dl & $114(108-120)$ & $142(132-157)$ & $<0.01^{*}$ \\
\hline LDL-C, median (95\% CI), mg/dl & $127(121-130)$ & $123(115-129)$ & 0.44 \\
\hline HDL-C, median (95\% CI), mg/dl & $50(49-51)$ & $42(40-43)$ & $<0.01^{*}$ \\
\hline \multicolumn{4}{|c|}{ 50-59 age } \\
\hline Parameters & Women $(n=577)$ & Men $(n=291)$ & $P$ \\
\hline SFer, median (95\% CI), ng/ml & $30(27-32)$ & $53(45-61)$ & $<0.01^{*}$ \\
\hline TC, median (95\% CI), mg/dL & $214(210-220)$ & 195 (191-203) & $<0.01^{*}$ \\
\hline TG, median (95\% CI), mg/dl & $131(123-135)$ & $140(134-148)$ & 0.06 \\
\hline LDL-C, median (95\% CI), mg/dl & $134(129-138)$ & $120(114-125)$ & $<0.01^{*}$ \\
\hline HDL-C, median (95\% CI), mg/dl & $50(49-51)$ & $43(41-44)$ & $<0.01^{*}$ \\
\hline \multicolumn{4}{|c|}{$60-70$ age } \\
\hline Parameters & Women $(n=381)$ & Men $(n=251)$ & $P$ \\
\hline SFer, median (95\% CI), ng/ml & 38 (34-41) & $52(45-60)$ & $<0.01^{*}$ \\
\hline TC, median (95\% CI), mg/dl & $214(210-219)$ & $189(182-196)$ & $<0.01^{*}$ \\
\hline TG, median (95\% CI), mg/dl & $131(125-138)$ & $128(114-136)$ & 0.49 \\
\hline LDL-C, median (95\% CI), mg/dl & $132(127-136)$ & $115(107-119)$ & $<0.01^{*}$ \\
\hline HDL-C, median (95\% CI), mg/dl & $53(52-55)$ & $42(41-44)$ & $<0.01^{*}$ \\
\hline
\end{tabular}

*Statistically significant difference $(P<0.05)$

SFer levels could be a marker indicating early coronary artery stenosis [32].

There is research suggesting that high SFer levels are also linked to metabolic syndrome and diabetes. Jehn et al. have found that in 6,044 Ameri- can adults, there was an association between SFer levels and prevalence of metabolic syndrome in both men and women [33]. Similar findings have been reported in a study of 8,441 people from different provinces of China [34]. Additionally, a disorder 
Ta b le 3. Correlation analysis of the serum parameters in the studied groups: combined and between genders

\begin{tabular}{l|c|c|c}
\hline \multicolumn{1}{c|}{ Parameters } & Combined group & Women $(n=3539)$ & Men $(n=1066)$ \\
\hline Ferritin \& TC & $r=0.080, P<0.01$ & $r=0.120, P<0.01$ & $r=-0.020, P=0.50$ \\
Ferritin \& TG & $r=0.234, P<0.01$ & $r=0.177, P<0.01$ & $r=0.080, P=0.01$ \\
Ferritin \& LDL-C & $r=0.103, P<0.01$ & $r=0.129, P<0.01$ & $r=-0.010, P=0.76$ \\
Ferritin \& HDL-C & $r=-0.247, P<0.01$ & $r=-0.090, P<0.01$ & $r=-0.177, P<0.01$ \\
\hline
\end{tabular}

Table 4. Comparison of SFer levels between subjects with normal lipid parameters and those with dyslipidemia, as classified by the National Cholesterol Education Program and Adult Treatment Panel III [28], $P<0.01$

\begin{tabular}{l|c}
\hline \multicolumn{1}{c|}{ Cut-off levels } & $\begin{array}{c}\text { Ferritin, median } \\
(95 \% \text { CI), ng/ml }\end{array}$ \\
\hline TC $<200$ & $20(18-21)$ \\
TC $\geq 200$ & $25(23-26)$ \\
TG $<150$ & $19(18-20)$ \\
TG $\geq 150$ & $31(28-34)$ \\
LDL-C $<100$ & $20(18-21)$ \\
LDL-C $\geq 100$ & $23(21-23)$ \\
HDL-C $<50$, women & $18(17-20)$ \\
HDL-C $\geq 50$, women & $15(14-16)$ \\
HDL-C $<40$, men & $73(62-82)$ \\
HDL-C $\geq 40$, men & $54(48-60)$ \\
\hline
\end{tabular}

most common in middle-aged men, named Dysmetabolic Iron Overload Syndrome (DIOS), is characterized by the clinical conditions of moderate rise in ferritin levels, normal transferrin saturation, nonalcoholic fatty liver disease (moderately elevated gamma-glutamyl transpeptidase), and increased iron load in hepatocytes and macrophages, together with insulin resistance or metabolic syndrome. It has been suggested that DIOS could be seen in approximately one third of patients with non-alcoholic fatty liver disease and metabolic syndrome, and that this condition may predispose to CVD and type-2 diabetes mellitus [24, 35, 36].

The molecular mechanism behind the link between increased iron overload and metabolic syndrome, cardiovascular diseases and other diseases is not fully understood. Among proposed pathophysiological mechanisms, the most possible one is the relationship between iron and oxidative stress. Iron is a strong pro-oxidant transition element. Due to this feature, it can cause cellular damage in different tissues by generating reactive oxygen species [24, 37]. Another possible mechanism could be based on Hevi et al.'s research [38]. This experimental study has shown that in hepatocytes, ferritin inhibits apolipoprotein B (apoB) secretion in a post-translational manner without affecting the secretion of apolipoprotein A-I, albumin or factor-XIII. Interestingly, the researchers have demonstrated that in these cells, triglyceride synthesis is not reduced and cellular triglyceride levels are in fact increased. As a result, our theory on the basis of this work is that by inhibiting apoB secretion and increasing triglyceride synthesis, ferritin increases intracellular lipid levels and leads to damage in hepatocytes, thus generating a similar pathology seen in DIOS.

Perhaps the most important finding of our study is that SFer levels in women, although remaining lower than those in men, increased with advancing age unlike in men (Table 2; Figure). It should be noted that levels of TC, TG and LDL-C also tended to increase with age, and peaked at the 50-59 ages subgroup (Table 2). Many studies have reported a higher risk of CVD especially in postmenopausal women [39]. This phenomenon has been attributed to the cessation of the menstrual cycle and the decline of related hormones. However, CVD risk is not diminished in women receiving hormone replacement therapy [39]. Increase in iron load in postmenopausal women has been shown both in our study and others. High iron stores may be primarily responsible for the elevated CVD risk in women and ferritin could be an important marker for monitoring CVD risk.

A study conducted in patients with hereditary hemochromatosis has shown that phlebotomy reduced TG levels without altering serum glucose or cholesterol levels [40]. Similarly, another study has found that phlebotomy reduced serum glucose and glycated hemoglobin levels, LDL/HDL ratio, and systolic blood pressure in patients with metabolic 
Table 5. Correlation analysis between SFer levels and activity levels of paraoxonase-1 (PON1) and arylesterase (ARE) in the studied groups: combined and between genders. PON1 and ARE activities were used for assessing HDL function

\begin{tabular}{l|c|c|c}
\hline \multicolumn{1}{c|}{ Parameters } & Combined group $(n=100)$ & Women $(n=52)$ & Men $(n=48)$ \\
\hline Ferritin \& HDL-C & $r=-0.446, P<0.01$ & $r=-0.368, P=0.03$ & $r=-0.590, P=0.02$ \\
Ferritin \& PON1 & $r=-0.193, P=0.14$ & $r=-0.219, P=0.23$ & $r=-0.128, P=0.43$ \\
Ferritin \& ARE & $r=-0.090, P=0.48$ & $r=-0.123, P=0.50$ & $r=0.060, P=0.76$ \\
\hline
\end{tabular}

syndrome [41]. Therefore, by keeping SFer levels low, phlebotomy can be a simple and effective prophylactic measure for both postmenopausal women and individuals that bear risk factors for metabolic syndrome and CVD. If such positive effects of phlebotomy can be proved by other studies in the future, phlebotomy not only will be used as a preventive tool for common chronic disorders such as metabolic syndrome, but also will help maintain blood supplies required for transfusion.

In all age subgroups of women, HDL-C levels were significantly higher compared to men in our study. On the other hand, it has been recently acknowledged that HDL functionality is more critical than its concentration [19, 42, 43]. PON1 and ARE, which are important indicators of HDL function, are multi-functional enzymes that have antioxidant, antiatherogenic, lactonase and homocysteine-thiolactonase activities [44, 45]. In our smaller group of 100 individuals, although there was a negative correlation between HDL-C and SFer levels, there was no correlation between SFer levels and PON1 or ARE activities. Moreover, there was no difference in
PON1 and ARE activities between genders. Therefore, although HDL levels in women were high in all age groups compared to men, no difference in HDL function was noted in the study.

The main limitation in our study was due to the fact that ferritin is a positive acute phase reactant. Unfortunately, we were unable to determine the presence of acute or chronic inflammation in our study group in order to exclude such individuals. Similarly, even though patients that suffer acutely from CVD (inpatients) were left out of the study group, follow-up patients with chronic CVD could not be excluded. Also, we could not factor socio-economic status and dietary habits, which can influence serum ferritin levels and iron stores, into our categorization of the study population.

In summary, we have examined the relationship between SFer levels and serum lipid parameters in each gender with respect to age in this study. In women in particular, increasing serum ferritin levels with advancing age, which is accompanied by higher serum TC, TG and LDL levels, may make postmenopausal women more prone to develop CVD
A

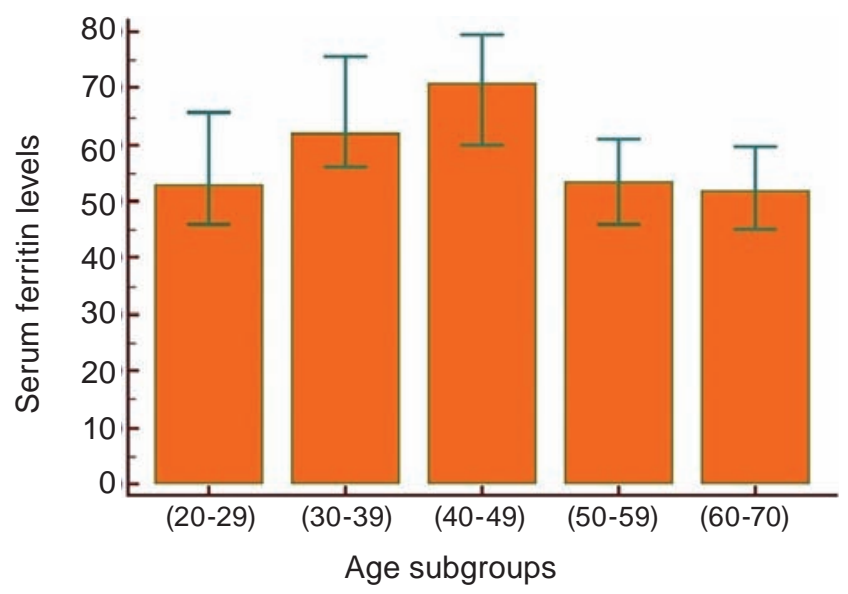

B

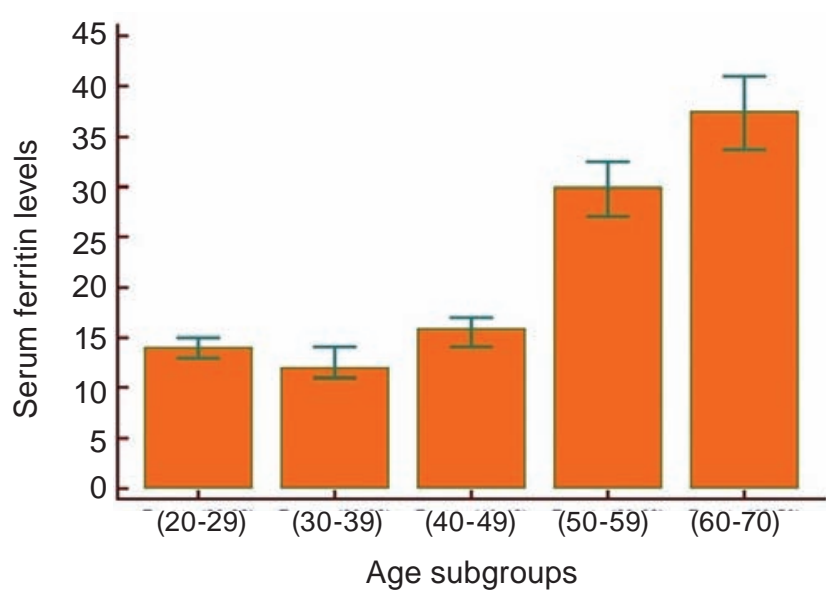

Distribution of SFer levels between age subgroups: A - Men. B - Women 
and metabolic diseases. Salonen et al.'s study has established a cut-off value of ferritin for men (a SFer level above $200 \mathrm{ng} / \mathrm{ml}$ increases risk of CVD by 2.2 fold in men), but a corresponding ferritin reference for women is lacking [12]. The need for such a study is evident, as SFer levels in men and women exhibit physiological variance. Thus, SFer levels could be monitored in postmenopausal women and, if necessary, the beneficial effects of phlebotomy could be utilized in order to prevent chronic diseases such as CVD and metabolic syndrome. Certainly, further large-scale studies are needed to support our hypotheses.

\section{Acknowledgements}

We thank Suha Sayrac for his assistance during revision of the manuscript.

\section{ВЗАСМОЗВ'ЯЗОК МІЖ РІВНЕМ СИРОВАТКОВИХ ФЕРИТИНУ, ЛІПІДІВ І ЛІПОПРОТЁ̈НІВ ВИСОКОЇ ЩІЛЬНОСТІ 3 УРАХУВАННЯМ ВІКУ І СТАТІ ЛЮДЕЙ}

\section{Hamit Yasar Ellidag ${ }^{1 *}$, Esin Eren ${ }^{1}$, Mehmet Akdag $^{2}$, Ozlem Giray ${ }^{1}$, Kemal Kiraz ${ }^{3}$, Necat Yilmaz $^{1}$}

${ }^{1}$ Central Laboratories of Antalya Training and Research Hospital, University of Medical Sciences, Ministry of Health, Antalya, Turkey; ${ }^{2}$ ENT Clinic of Antalya Ataturk State Hospital, Ministry of Health, Antalya, Turkey; ${ }^{3}$ Department of Pulmonology, Antalya Ataturk State Hospital, Ministry of Health, Antalya, Turkey; e-mail: hayael1980@hotmail.com

Підвищений рівень сироваткового феритину (СФер) пов'язують із хронічними серцево-судинними захворюваннями та діабетом 2-го типу. Метою дослідження було вивчення взаємозв'язку між рівнями СФер і ліпідами сироватки крові на тлі віку і статі людей. Досліджували можливий взаємозв'язок між СФер і ліпопротеїнами високої щільності (ЛВЩ). Рівень СФер і ліпідної панелі: загальний холестерол (3Х), тригліцероли (ТГ), ліпопротеїн-холестерол низької щільності (ЛНЩ-Х) i ліпопротеїн-холестерол високої щільності (ЛВЩ-Х) ретроспективно досліджено у 4205 осіб (3139 жінок і 1066 чоловіків). Досліджувані групи було розділено відповідно до віку і статті. У 52 жінок і 48 чоловіків досліджували взаємозв'язок між рівнем СФер i активністю ЛВЩ-залежної параоксонази-1 (ПОН1) і арілестерази (АРЕ). У всіх вікових групах рівень СФер у жінок був значно нижче, а рівень ЛВЩ-Х значно вище, ніж у чоловіків. Показано, що у віці 50-70 років рівні 3Х і ЛНЩ-Х у жінок були вищі, ніж у чоловіків $(P<0,01)$. Рівень СФер мав тенденцію до підвищення в літніх жінок. Встановлено негативну кореляцію між рівнями СФер і ЛВЩ-Х, у той час як між рівнями СФер і ЗХ, ТГ і ЛНЩ-Х існувала позитивна кореляція. Не спостерігалося істотної кореляції між рівнями активності ПОН1 і АРЕ. Таким чином, факт підвищення рівня СФер одночасно із підвищенням рівнів ЗХ, ТГ і ЛНЩ-Х може допомогти пояснити збільшення ризику обмінних порушень і серцево-судинних захворювань у жінок у менопаузі.

Ключ ов і слов а: феритин, ліпідний обмін, параоксоназа, ЛВЩ, ЛНЩ.

\section{ВЗАИМОСВЯЗЬ МЕЖДУ УРОВНЕМ СЫВОРОТОЧНЫХ ФЕРРИТИНА, ЛИПИДОВ И ЛИПОПРОТЕИНОВ ВЫСОКОЙ ПЛОТНОСТИ С УЧЕТОМ ВОЗРАСТА И ПОЛА ЛЮДЕЙ}

\author{
Hamit Yasar Ellidag ${ }^{1 *}$, Esin Eren ${ }^{1}$, Mehmet \\ Akdag $^{2}$, Ozlem Giray ${ }^{1}$, Kemal Kiraz ${ }^{3}$, Necat \\ Yilmaz $^{1}$ \\ ${ }^{1}$ Central Laboratories of Antalya Training \\ and Research Hospital, University of Medical \\ Sciences, Ministry of Health, Antalya, Turkey; \\ ${ }^{2}$ ENT Clinic of Antalya Ataturk State Hospital, \\ Ministry of Health, Antalya, Turkey; \\ ${ }^{3}$ Department of Pulmonology, Antalya Ataturk State \\ Hospital, Ministry of Health, Antalya, Turkey; \\ e-mail: hayael1980@hotmail.com
}

Повышенный уровень сывороточного ферритина (СФер) связывают с хроническими сердечно-сосудистыми заболеваниями и диабетом 2-го типа. Целью исследования было изучение взаимосвязи между уровнями СФер и липидов сыворотки крови с учетом возраста и пола людей. Исследовали также возможную взаимосвязь между уровнем СФер и функцией липопротеинов высокой плотности (ЛВП). Уровень СФер и липидной панели: общий холестерол (ОХ), триглицеролы (ТГ), липопротеин-холестерол низкой плотности (ЛНП-Х) и липопротеин- 
холестерол высокой плотности (ЛВП-Х) ретроспективно были исследованы у 4205 человек (3139 женщин и 1066 мужчин). Исследуемые группы разделили в соответствии с возрастом и полом. У 52 женщин и 48 мужчин исследовали взаимосвязь между уровнем СФер и активностью ЛВП-зависимой параоксоназы-1 (ПОН1) и арилэстеразы (АРЭ). Во всех возрастных группах уровень СФер у женщин был значительно ниже, а уровень ЛВП-Х значительно выше, чем у мужчин. Показано, что в возрасте 50-70 лет уровни OX и ЛНП-Х у женщин были выше, чем у мужчин $(P<0,01)$. Уровень СФер у пожилых женщин имел тенденцию к повышению. Установлена негативная корреляция между уровнями СФер и ЛВП-Х, в то время как между уровнями СФер и ОХ, ТГ и ЛНП-Х корреляция была позитивной. Не наблюдалось существенной корреляции между уровнями активности ПОН1 и АРЭ. Таким образом, факт повышения уровня СФер одновременно с повышением ОХ, ТГ и ЛНП-Х может помочь объяснить увеличение риска обменных нарушений и сердечно-сосудистых заболеваний у женщин в менопаузе.

К л ю ч е в ы е с л о в а: ферритин, липидный обмен, параоксоназа, ЛВП, ЛНП.

\section{References}

1. Aydin O, Ellidag HY, Eren E, Kurtulus F, Yaman A, Y1lmaz N. Ischemia modified albumin is an indicator of oxidative stress in multiple sclerosis. Biochem Med (Zagreb). 2014; 24(3): 383-389.

2. Kell DB. Iron behaving badly: inappropriate iron chelation as a major contributor to the aetiology of vascular and other progressive inflammatory and degenerative diseases. BMC Med Genomics. 2009; 2: 2.

3. Saito H. Metabolism of iron stores. Nagoya $J$ Med Sci. 2014; 76(3-4): 235-254.

4. Pisano G, Lombardi R, Fracanzani AL. Vascular Damage in Patients with Nonalcoholic Fatty Liver Disease: Possible Role of Iron and Ferritin. Int J Mol Sci. 2016; 17(5). pii: E675.

5. Fu S, Li F, Zhou J, Liu Z. The Relationship Between Body Iron Status, Iron Intake And Gestational Diabetes: A Systematic Review and Meta-Analysis. Medicine (Baltimore). 2016; 95(2): e2383.

6. Ahluwalia N, Genoux A, Ferrieres J, Perret B, Carayol M, Drouet L, Ruidavets JB. Iron status is associated with carotid atherosclerotic plaques in middle-aged adults. $J$ Nutr. 2010; 140(4): 812816.

7. Ellidag HY, Kurtulus F, Yaman A, Eren E, Yılmaz N, Aydin O, Bayındır A. Serum iron metabolism markers including hepcidin in multiple sclerosis patients. Neurochem J. 2014; 8(3): 226-230.

8. Jiang R, Manson JE, Meigs JB, Ma J, Rifai N, Hu FB. Body iron stores in relation to risk of type 2 diabetes in apparently healthy women. JAMA. 2004; 291(6): 711-717.

9. Sempos CT, Looker AC, Gillum RE, McGee DL, Vuong CV, Johnson CL. Serum ferritin and death from all causes and cardiovascular disease: the NHANES II Mortality Study. National Health and Nutrition Examination Study. Ann Epidemiol. 2000; 10(7): 441-448.

10. Sempos CT. Do body iron stores increase the risk of developing coronary heart disease? Am J Clin Nutr. 2002; 76(3): 501-503.

11. Sullivan JL. Iron and the sex difference in heart disease risk. Lancet. 1981 Jun 13;1(8233):1293-4.

12. Salonen JT, Nyyssönen $K$, Korpela $H$, Tuomilehto J, Seppänen R, Salonen R. High stored iron levels are associated with excess risk of myocardial infarction in eastern Finnish men. Circulation. 1992; 86(3): 803-811.

13. Choi KM, Lee KW, Kim HY, Seo JA, Kim SG, Kim NH, Choi DS, Baik SH. Association among serum ferritin, alanine aminotransferase levels, and metabolic syndrome in Korean postmenopausal women. Metabolism. 2005; 54(11): 1510-1514.

14. Valenti L, Maloberti A, Signorini S, Milano M, Cesana F, Cappellini F, Dongiovanni P, Porzio M, Soriano F, Brambilla M, Cesana G, Brambilla P, Giannattasio C, Fargion S. Iron Stores, Hepcidin, and Aortic Stiffness in Individuals with Hypertension. PLoS One. 2015; 10(8): e0134635.

15. Aronow WS, Ahn C. Three-year follow-up shows no association of serum ferritin levels with incidence of new coronary events in 577 persons aged $>$ or $=62$ years. Am J Cardiol. 1996; 78(6): 678-679.

16. Magnusson MK, Sigfusson N, Sigvaldason H, Johannesson GM, Magnusson S, Thorgeirsson G. Low iron-binding capacity as a risk factor for myocardial infarction. Circulation. 1994; 89(1): 102-108. 
17. Mänttäri M, Manninen V, Huttunen JK, Palosuo T, Ehnholm C, Heinonen OP, Frick MH. Serum ferritin and ceruloplasmin as coronary risk factors. Eur Heart J. 1994; 15(12): 15991603.

18. Stampfer MJ, Grodstein F, Rosenberg I, Willett WC, Hennekens C. A prospective study of plasma ferritin and risk of myocardial infarction in US physicians [Abstract]. Circulation. 1993; 87: 688.

19. Eren E, Ellidag HY, Aydin O, Yilmaz N. HDL functionality and crystal-based sterile inflammation in atherosclerosis. Clin Chim Acta. 2015 ; 439: 18-23.

20. Kannel WB, Castelli WP, Gordon T. Cholesterol in the prediction of atherosclerotic disease. New perspectives based on the Framingham study. Ann Intern Med. 1979; 90(1): 85-91.

21. Kamei A, Watanabe Y, Ishijima T, Uehara M, Arai S, Kato H, Nakai Y, Abe K. Dietary irondeficient anemia induces a variety of metabolic changes and even apoptosis in rat liver: a DNA microarray study. Physiol Genomics. 2010; 42(2): 149-156.

22. Choi JW, Kim SK, Pai SH. Changes in serum lipid concentrations during iron depletion and after iron supplementation. Ann Clin Lab Sci. 2001; 31(2): 151-156.

23. Ozdemir A, Sevinç C, Selamet U, Türkmen F. The relationship between iron deficiency anemia and lipid metabolism in premenopausal women. Am J Med Sci. 2007; 334(5): 331-333.

24. Basuli D, Stevens RG, Torti FM, Torti SV. Epidemiological associations between iron and cardiovascular disease and diabetes. Front Pharmacol. 2014; 5: 117.

25. Friedewald WT, Levy RI, Fredrickson DS. Estimation of the concentration of low-density lipoprotein cholesterol in plasma, without use of the preparative ultracentrifuge. Clin Chem. 1972; 18(6): 499-502.

26. Eckerson HW, Wyte CM, La Du BN. The human serum paraoxonase/arylesterase polymorphism. Am J Hum Genet. 1983; 35(6): 1126-138.

27. Haagen L, Brock A. A new automated method for phenotyping arylesterase (EC 3.1.1.2) based upon inhibition of enzymatic hydrolysis of 4-nitrophenyl acetate by phenyl acetate. Eur $J$ Clin Chem Clin Biochem. 1992; 30(7): 391-395.
28. Expert Panel on Detection, Evaluation, and Treatment of High Blood Cholesterol in Adults. Executive Summary of The Third Report of The National Cholesterol Education Program (NCEP) Expert Panel on Detection, Evaluation, And Treatment of High Blood Cholesterol In Adults (Adult Treatment Panel III). JAMA. 2001; 285(19): 2486-2497.

29. Tuomainen TP, Punnonen K, Nyyssönen K, Salonen JT. Association between body iron stores and the risk of acute myocardial infarction in men. Circulation. 1998; 97(15): 1461-1466.

30. van der A DL, Grobbee DE, Roest M, Marx JJ, Voorbij HA, van der Schouw YT. Serum ferritin is a risk factor for stroke in postmenopausal women. Stroke. 2005; 36(8): 1637-1641.

31. Wolff B, Völzke H, Lüdemann J, Robinson D, Vogelgesang D, Staudt A, Kessler C, Dahm JB, John U, Felix SB. Association between high serum ferritin levels and carotid atherosclerosis in the study of health in Pomerania (SHIP). Stroke. 2004; 35(2): 453-457.

32. Sung KC, Kang SM, Cho EJ, Park JB, Wild SH, Byrne CD. Ferritin is independently associated with the presence of coronary artery calcium in 12,033 men. Arterioscler Thromb Vasc Biol. 2012; 32(10): 2525-2530.

33. Jehn M, Clark JM, Guallar E. Serum ferritin and risk of the metabolic syndrome in U.S. adults. Diabetes Care. 2004; 27(10): 2422-2428.

34. Li J, Wang R, Luo D, Li S, Xiao C. Association between serum ferritin levels and risk of the metabolic syndrome in Chinese adults: a population study. PLoS One. 2013; 8(9): e74168.

35. Barisani D, Pelucchi S, Mariani R, Galimberti S, Trombini P, Fumagalli D, Meneveri R, Nemeth E, Ganz T, Piperno A. Hepcidin and iron-related gene expression in subjects with Dysmetabolic Hepatic Iron Overload. J Hepatol. 2008; 49(1): 123-133.

36. Datz C, Felder TK, Niederseer D, Aigner E. Iron homeostasis in the metabolic syndrome. Eur $J$ Clin Invest. 2013; 43(2): 215-224.

37. Shizukuda Y, Tripodi DJ, Rosing DR. Iron Overload or Oxidative Stress? Insight into a Mechanism of Early Cardiac Manifestations of Asymptomatic Hereditary Hemochromatosis Subjects with C282Y Homozygosity. J Cardiovasc Transl Res. 2016; 9(4): 400-401. 
38. Hevi S, Chuck SL. Ferritins can regulate the secretion of apolipoprotein B. J Biol Chem. 2003; 278(34): 31924-31929.

39. Cífková R, Krajčoviechová A. Dyslipidemia and cardiovascular disease in women. Curr Cardiol Rep. 2015; 17(7): 609.

40. Casanova-Esteban P, Guiral N, Andrés E, Gonzalvo C, Mateo-Gallego R, Giraldo P, Paramo JA, Civeira F. Effect of phlebotomy on lipid metabolism in subjects with hereditary hemochromatosis. Metabolism. 2011; 60(6): 830-834.

41. Houschyar KS, Lüdtke R, Dobos GJ, Kalus U, Broecker-Preuss M, Rampp T, Brinkhaus B, Michalsen A. Effects of phlebotomy-induced reduction of body iron stores on metabolic syndrome: results from a randomized clinical trial. BMC Med. 2012; 10: 54.
42. Ellidag HY, Eren E, Aydin O, Yıldırım M, Sezer C, Yilmaz N. Multiple myeloma: relationship to antioxidant esterases. Med Princ Pract Int J Kuwait Univ Health Sci Cent. 2014; 23(1): 18-23.

43. Eren E, Yilmaz N, Aydin O. High Density Lipoprotein and it's Dysfunction. Open Biochem J. 2012; 6: 78-93.

44. Ellidag HY, Aydin O, Eren E, Yilmaz N, Ergin M. Decreased HDL-dependent paraoxonase and arylesterase enzyme activity may indicate a worse prognosis in multiple myeloma. Asian Pac J Cancer Prev. 2014; 15(22): 9847-9851.

45. Ellidag HY, Aydin O, Eren E, Yilmaz N, Gencpinar T, Kucukseymen S, Yilmaz A, Ince FDA. Phenotype distribution of the paraoxonase gene in patients with cardiac disease. Arch Med Sci. 2016: 1-7.

Received 26.09.2016 